\title{
Effects of a 'one film for 2 years' system on the grain yield, water use efficiency and cost-benefit balance in dryland spring maize (Zea mays L.) on the Loess Plateau, China
}

\author{
Baoqing Chen, Changrong Yan, Sarah Garré, Xurong Mei \& Enke Liu
}

To cite this article: Baoqing Chen, Changrong Yan, Sarah Garré, Xurong Mei \& Enke Liu (2017): Effects of a 'one film for 2 years' system on the grain yield, water use efficiency and cost-benefit balance in dryland spring maize (Zea mays L.) on the Loess Plateau, China, Archives of Agronomy and Soil Science, DOI: 10.1080/03650340.2017.1393530

To link to this article: http://dx.doi.org/10.1080/03650340.2017.1393530

Accepted author version posted online: 16

Oct 2017.

Submit your article to this journal

Џll Article views: 1

View related articles

View Crossmark data \lceil 
Publisher: Taylor \& Francis

Journal: Archives of Agronomy and Soil Science

DOI: $10.1080 / 03650340.2017 .1393530$

Effects of a 'one film for 2 years' system on the grain yield, water use efficiency and costbenefit balance in dryland spring maize (Zea mays L.) on the Loess Plateau, China

Baoqing Chen ${ }^{\mathrm{a}, \mathrm{b}}$, Changrong Yan ${ }^{\mathrm{a}}$, Sarah Garré ${ }^{\mathrm{b}}$, Xurong Mei ${ }^{\mathrm{a}}$, Enke Liu ${ }^{\mathrm{a}}$

${ }^{\text {a }}$ State Engineering Laboratory of Efficient Water Use of Crops and Disaster Loss Mitigation/ Key Laboratory for Dryland Agriculture, Institute of Environment and Sustainable Development in Agriculture, Chinese Academy of Agriculture Sciences, Beijing, China;

${ }^{\mathrm{b}}$ Terra Research Center, Gembloux Agro-Bio Tech, University of Liège, Gembloux, Belgium.

CONTACT: Enke Liu; State Engineering Laboratory of Efficient Water Use of Crops and Disaster Loss Mitigation/ Key Laboratory for Dryland Agriculture, Institute of Environment and Sustainable Development in Agriculture, Chinese Academy of Agriculture Sciences, Beijing, China; Email: liuenke@caas.cn

\begin{abstract}
'One film for 2 years' (PM2) has been proposed as a practice to control the residual film pollution; however, its effects on grain-yield, water-use-efficiency and cost-benefit balance in dryland spring maize production have still not been systematically explored. In this study, we compared the performance of PM2 with the annual film replacement treatment (PM1) and no mulch treatment (CK) on the Loess Plateau in 2015-2016. Our results indicated the following: (1) PM2 was effective at improving the topsoil moisture $(0-20 \mathrm{~cm})$ at sowing time and at seedling stage, but there was no significant influence on soil water storage, seasonal average
\end{abstract}


soil moisture or evapotranspiration; (2) PM2 induced significantly higher cumulative soil temperatures compared to $\mathrm{CK}$, and there was no significant difference between PM2 and PM1;

(3) no significant differences were identified in grain-yield and water-use-efficiency between PM1 and PM2, and compared to CK, they improved by $16.3 \%$ and $15.5 \%$, respectively; (4) because of lower cost of plastic film, tillage, film laying and remove in PM2, economic profits improved by $21 \%$ and $70 \%$ compared to PM1 and CK. This research suggested that PM2 was effective at alleviating the spring drought and was beneficial in reducing poverty traps in dryland.

Keywords: plastic mulching; soil water; maize yield; water use efficiency; cost-benefit

\section{Introduction}

Achieving high yields on existing croplands with less impact on the environment is one of the most important issues for agricultural sustainable development, and this challenge requires changes in the way food is produced (Godfray et al. 2010; Tilman et al. 2011). Plastic mulching is important for crop production in China, and from 1991 to 2011, there has been a four-fold increase in plastic mulch use (National Bureau of Statistics of China 2014), which has generated important improvements in crop production (Liu et al. 2014; Qin et al. 2015). However, accumulation of plastic residues in soil is becoming increasingly serious, and a typical survey in China demonstrates that the residual amount in soil has reached 71.9-259.1 $\mathrm{kg} \cdot \mathrm{hm}^{-2}$ (Yan et al. 2014). It poses a direct threat to soil health and crop production (Dong et al. 2013; Guo et al. 2016; Niu et al. 2016) and also leads to high loads of phthalate esters in agricultural soils (Chen et al. 2013).

Development of film use frequency reduction, biodegradable film and machinery designed for residual film recovery are three possible ways to control plastic film pollution (Yan et al. 2014; Liu et al. 2014). Using one film for two or more years ('one film for two 
years' or 'one film for multiple years') is one of the technologies used to reduce film use frequency. Current plastic mulching technology has been characterized by annually replacing film, and the residual film is usually directly incorporated into the soil during tillage because of its low recycling value. In a 'one film for two years' or 'one film for multiple years' system, the frequency of plastic film use will be reduced by $50 \%$ or more. This is not an approach to eliminate residual film pollution at the source but will effectively alleviate the accumulation of plastic in soil. Although the concept of 'one film for two years' or 'one film for multiple years' has been proposed in previous research (He et al. 2009; Yan et al. 2014), its potential influences on grain yield, water use efficiency and cost-benefit balance have not been systematically explored in dryland spring maize production.

Spring maize is one of the most important grain crops in the drylands of China. While climate conditions for dryland spring maize are usually characterized by strong evaporation and rare precipitation in fallow periods, they may limit the soil moisture conditions at sowing and even lead to yield failures (Cai et al. 2015; Wu et al. 2017). Wu et al. (2017) proposed a whole season plastic mulching model to solve this problem and suggested that mulching practices during the fallow period relieved drought during the early stage of spring maize. A 'one film for two years' or 'one film for multiple years' system may have similar effects because plastic film is not removed during the fallow period. However, this effect is still not fully understood.

The proportion of humans living in poverty is extremely high on global drylands (UNDP 2006). In China, more than $80 \%$ of absolute poverty is distributed on drylands (National Bureau of Statistics of China 2014), and most impoverished communities depend on farmland for survival. Plastic mulching is a common agricultural practice on drylands, and improving its economic profitability would help to alleviate poverty. Hence, it is necessary to evaluate the cost-benefit balance of film use frequency based on its influence on crop yields. In fact, a 'one film for two years' or 'one film for multiple years' system will save input costs of plastic 
film and field management; however, its influence on crop yield is still unknown and is dependent on its influence on soil water and temperature conditions (Tarara 2000; Zhou et al. 2009).

The objective of this research was to evaluate the effects of reducing film use frequency on maize grain yields, water use efficiency and cost-benefit balance in dryland spring maize crop production. We hypothesized that reducing film use frequency is beneficial for improving soil moisture conditions and economic benefits. To verify this assumption, we designed a 'one film for two years' system for dryland spring maize production on the Loess Plateau, and its performance was compared with an annual film replacement treatment and a no mulch treatment.

\section{Materials and methods}

\section{Research site}

The field experiment was conducted in 2015 and 2016 at the Shouyang rain-fed agricultural experimental station $\left(37^{\circ} 45^{\prime} \mathrm{N}, 113^{\circ} 12^{\prime} \mathrm{E}, 1080 \mathrm{~m}\right.$ altitude), Shanxi, China. The climate at the research site is semi-arid according to the UNEP classification system (UNEP 1992). Under average climatic conditions, the area receives $480 \mathrm{~mm}$ of precipitation annually, about $70 \%$ of which occurs in the summer from June until September. The conventional cropping system is continuous maize cultivation. Usually, maize is sown from late April early May and harvested in late September - early October. The soil texture is classified as loam under the USDA soil texture classification system and is classified as Calcaric Cambisol according to the world reference base for soil resources (FAO 2006). The top $20 \mathrm{~cm}$ of soil had a $\mathrm{pH}$ of 7.8 , soil organic matter content of $18.03 \mathrm{~g} \mathrm{~kg}^{-1}$, total $\mathrm{N}$ of $0.85 \mathrm{~g} \mathrm{~kg}^{-1}$, total $\mathrm{P}$ of $0.63 \mathrm{~g} \mathrm{~kg}^{-1}$, and total $\mathrm{K}$ of $19.39 \mathrm{~g} \mathrm{~kg}^{-1}$.

The solar radiation, rainfall amount, air temperature, relative humidity, and wind speed were obtained every half-hour using an automatic weather station (Campbell Scientific Inc., 
Logan, UT, USA) near the experimental plots. Solar radiation was measured with a Silicon Pyranometer (LI200X, LI-COR, Inc., Lincoln, NE, USA). Precipitation was registered with a pluviometer (RGB1, Campbell Scientific Inc., Logan, UT, USA). Air temperature and relative humidity were measured using a Vaisala probe (HMP45C, Vaisala Inc., Tucson, AZ, USA). Wind speed was measured using a cup anemometer (03002-L, R.M. Young Inc., Traverse, MI, USA). These measurements were taken $2 \mathrm{~m}$ above the surface of grassland and recorded in a data-logger (CR10RX, Campbell Scientific Inc., Logan, UT, USA). With those obtained variables, the reference crop evapotranspiration $\left(\mathrm{ET}_{0}, \mathrm{~mm} / \mathrm{d}\right)$ was computed using the Penman-Monteith combination equation using relevant meteorological data (Allen et al. 1998).

Following the direction of FAO-56 (Allen et al. 1998), the potential evaporation during the fallow period was approximatively calculated as a product of $\mathrm{ET}_{0}$ and the crop coefficient in the initial stage of the growing season $\left(\mathrm{K}_{\mathrm{c} \text { ini }}\right)$. In this research, $\mathrm{K}_{\mathrm{c} \text { ini }}$ was obtained graphically from Allen et al. (1998) according to the average interval between wetting events, the evaporation power $\mathrm{ET}_{0}$, and the importance of the wetting event, and it was set as 0.4.

During the growing season of 2015, the cumulative precipitation reached $337.4 \mathrm{~mm}$, which was $20 \%$ lower than the 30 -year average precipitation of $421 \mathrm{~mm}$ in the growing season (May to September). Two peaks of precipitation occurred on the $86^{\text {th }}$ day after sowing (August 3) and the $123^{\text {rd }}$ day (September 8). During the 2016 corn-growing season, the cumulative precipitation was $406.1 \mathrm{~mm}$, which was slightly lower (3.5\%) than the average precipitation. A precipitation peak occurred on the $77^{\text {th }}$ day after sowing (July 20), and it was $130.7 \mathrm{~mm}$.

\section{Experimental design and field management}

We applied three treatments: (1) field without plastic mulching (CK) - in this system, the field was not covered by plastic film; (2) replacing film annually (PM1) - the soil was partially covered by plastic film, which was replaced yearly; and (3) 'one film for 2 years' 
(PM2) - when the crop was harvested, the plastic film was kept in place and soil tillage was not carried out. In this study, partial plastic mulching pattern and plastic film with thickness of $10 \mu \mathrm{m}$ was used. On the two sides of each mulched stripe band ( $80 \mathrm{~cm}$ width), no-mulched stripe bands with width of $40 \mathrm{~cm}$ were set to provide space for tractor to travel and farmer to walk and avoid film damage caused by wheels rolling or farmer trampling during weeding and harvest. The plastic film was therefore re-used in the second year. The experiment employed a completely randomized design with three replicates, and each plot area measured $60 \mathrm{~m}^{2}(6 \times 10 \mathrm{~m})$. Corresponding operation methods for CK, PM1 and PM2 are described below: Tillage Rotary tillage was carried out for all three treatments in the first year with a small walking tractor with a tillage depth of about $30 \mathrm{~cm}$; for the second year, no-tillage was applied in PM2, and rotary tillage was carried out for CK and PM1. Tillage was carried out about 5-10 days before sowing.

\section{Fertilization}

In accordance with local practice, fertilizers were applied at rates of $225 \mathrm{~kg} \mathrm{~N}^{-1}$ (Urea), 162 $\mathrm{kg} \mathrm{P}_{2} \mathrm{O}_{5}$ ha $^{-1}$ (Calcium superphosphate), and $45 \mathrm{~kg} \mathrm{~K}_{2} \mathrm{O} \mathrm{ha}^{-1}$ (Potassium chloride) before sowing without topdressing, and in 2015 , fertilizers were applied into the furrows in bare strips and mulch strips in PM1 and PM2, before the film was laid out. In 2016, to protect the plastic film in PM2, fertilizers were only applied in the furrows in bare strips.

\section{Plastic film application and maize sowing}

Clear and impermeable polyethylene (PE) film with a width of $80 \mathrm{~cm}$ and thickness of $10 \mu \mathrm{m}$ was used. Two shallow furrows were dug with a spade, and then the film edges were fixed in the furrow with the excavated soil. This led to soil coverage of about $67 \%$ with the plastic film. For PM1 and the first growing season of PM2, spring maize was sown directly into the film using a hole-sowing tool with a row distance of $60 \mathrm{~cm}$ and plant spacing of $30 \mathrm{~cm}$ 
(sowing density 55,556 plants ha ${ }^{-1}$ ). The maize cultivar "Qiangsheng 51" was sown on May $1^{\text {st }}, 2015$, and on May $5^{\text {th }}, 2016$. In filed with plastic mulching, because the plastic film was impermeable, rainfall may infiltrate into soil through three pathways:(1) part of rainfall was intercepted by the maize leaves and transferred along the stem into planting hole; for the other part, it (2) reached the ground directly and infiltrated into the bare soil, or (3) reached the surface of plastic film and horizontally flowed into the bare soil through the film side.

\section{Seedling thinning and weeding}

After seedling emergence, seedling thinning was carried out manually, and an herbicide mixture of 2,4-D butylate, paraquat, Dijie ${ }^{\circledR}$ and Baoguan ${ }^{\circledR}$ was used to control weeds.

\section{Harvest, straw and film removal}

In 2015, maize was harvested on September $30^{\text {th }}$, and in 2016, maize was harvested on October $1^{\text {st }}$. After harvest, all of the maize stubble was removed from the field manually and then used as animal fodder. In the PM1 treatment, the film was removed manually on October $1^{\text {st }}$ in 2015. In PM2, the film was kept on the soil surface after harvest in 2015 and removed on October $2^{\text {nd }}, 2016$.

\section{Soil water content}

The soil water content was determined gravimetrically $(\mathrm{w} / \mathrm{w})$. To understand the water storage change, before sowing and after harvest in each growing season, the soil water content was determined to a depth of $2 \mathrm{~m}$ at $0.1-\mathrm{m}$ intervals using a $0.06-\mathrm{m}$ diameter hand auger in bare soil and mulched soil. Furthermore, we determined the soil water content during the growing season to a depth of $1 \mathrm{~m}$ (0.1-m intervals) every 10 days in order to obtain information about the soil water dynamics. This was done using a finer hand auger $(0.03-\mathrm{m}$ diameter), to limit soil disturbance caused by sampling as much as possible. When the weather did not allow sampling on the planned date (due to, e.g., heavy rainfall), sampling was postponed for 1-2 days. In order to take into account inherent soil heterogeneity, we randomly sampled three positions on each plot every time, and their average value was used 
for the final statistical analysis. After that, the volumetric water content (VWC) was obtained by multiplying the gravimetric water content with the bulk density and then divided by the water density. Soil water storage $\left(\mathrm{W}_{\mathrm{s}}\right)$, evapotranspiration $(\mathrm{ET})$, and water use efficiency (WUE) were calculated according to Cai et al. (2015):

$$
\begin{gathered}
\mathrm{W}_{\mathrm{s}}=\sum_{\mathrm{i}}^{\mathrm{n}}\left(h_{i} \times \theta_{v i}\right) \times 10 \\
E T=\mathrm{P}-\left(W_{\text {s-sowing }}-W_{\text {s-harvest }}\right)
\end{gathered}
$$

where $\mathrm{W}_{\mathrm{s}}(\mathrm{mm})$ is the soil water storage for $0-200 \mathrm{~cm}$; $\mathrm{h}(\mathrm{cm})$ is the depth interval of the soil sample; $\theta_{\mathrm{v}}$ is the soil gravimetric water content $(\%), \mathrm{i}$ is the soil layer; $\mathrm{n}$ is the number of soil layers; ET $(\mathrm{mm})$ is the evaporation of water from the soil surface plus transpiration from the crop; and $\mathrm{W}_{\text {s-sowing }}(\mathrm{mm})$ and $\mathrm{W}_{\text {s-harvest }}(\mathrm{mm})$ are the soil water storage before sowing and after harvest, respectively.

WUE $\left(\mathrm{kg} \mathrm{ha}^{-1} \mathrm{~mm}^{-1}\right)$ was calculated as the grain yield divided by the seasonal ET.

\section{Soil temperature and soil thermal properties}

Temperature sensors (HIOKI 3633-20, Hioki E.E. Corporation, Japan) were installed in each plot at 5-cm depth between the plant rows. The soil temperature was recorded every half hour automatically from sowing until harvest, and then the mean daily temperature was calculated. The soil thermal time $\left(\mathrm{TT}_{\text {soil }}, \quad\right)$ was calculated using the following equation (McMaster and Wilhelm 1997):

$$
\mathrm{TT}_{\text {soil }}=\sum\left(\mathrm{T}_{\text {mean }}-\mathrm{T}_{\text {base }}\right)
$$

where $T_{\text {base }}$ is the base temperature of 10 for maize growth (Miedema 1982), and $T_{\text {mean }}$ is the daily mean soil temperature. When $\mathrm{T}_{\text {mean }}<\mathrm{T}_{\text {base, }} \mathrm{TT}_{\text {soil }}$ was considered to be 0 , which means that this day makes no contribution to the cumulative soil thermal time.

\section{Dry matter accumulation and maize yield}

Above ground dry matter 
For each plot composed of 12 rows, 3 plants were selected every month from the $3^{\text {rd }}, 4^{\text {th }}, 9^{\text {th }}$ and $10^{\text {th }}$ rows. The shoots were cut at ground level, and then the total shoot biomass was determined gravimetrically after oven drying at 105 for 30 min initially and then at 75 for $48 \mathrm{~h}$.

\section{Maize yield}

The center 4 rows in each plot were selected to measure maize yield, and for each row, the center $5 \mathrm{~m}$ was manually hand-harvested in early October. The grains were manually removed from the cobs and weighed; subsamples of approximately $1 \mathrm{~kg}$ per plot were weighed fresh, oven-dried to a constant weight at 70 and re-weighed to determine the water content (Cakir 2004). The grain yield per plot was also calculated on a "wet-mass basis" (standard water content of 15.5\%) (Payero et al. 2008).

\section{Cost-benefit analysis}

In this study, the cost-benefit analysis adopted the cost-benefit accounting system for agricultural productions of National Development and Reform Commission (NDRC) of the government of the People's Republic of China (NDRC 2016), in which the cost included input materials, cost for service, labor cost, and opportunity cost for self-supporting farmland or land rent, and the benefits came from agricultural productions. The opportunity cost for selfsupporting farmland meant the lost earning from renting out farmland when farmers managed their farmland by themselves. In our case, the cost mainly included cost for input materials (seed, fertilizer, pesticides, and plastic film); the cost for machinery service (tillage, sowing, film laying and maize harvest); the cost for labour (seedling thinning, herbicide spraying, straw remove, film remove, grain drying and threshing) and the opportunity cost for selfsupporting farmland. The benefits mainly came from maize grain sale.

In this study, the farm gate prices for seed, pesticides were obtained from five stores in Shouyang county. Prices for fertilizer, film, labour, maize, and opportunity cost for self- 
supporting farmland were obtained from government statistics in 2015 (NDRC 2016) (Table $1)$.

It should be noted that although tillage, sowing, film laying and harvesting were completed manually in the experiment, we used the local market price of machinery service in the calculations to reflect actual production. In actual production, the film laying and maize sowing were usually completed by an integrative machine which was pulled by small wheeled tractor and could complete maize sowing and film laying at the same time, and rotary tillage was usually completed by a medium sized wheel tractor before sowing, and the harvest was usually completed by a two-line or multi-line backpack harvester. In China, farmer usually rented machinery to do those work and they paid to the machine owners by the area. The prices of machinery services were obtained through a survey in three villages of Shouyang county (Table 1).

Similar to Guto et al. (2011), the labour used for seedling thinning, straw remove, film remove, herbicide spraying, grain drying and threshing in this study was monitored on the trial field and corroborating them against estimates of 20 farmers neighboring the trial site. The work rates for seedling thinning, straw remove, film remove, herbicide spraying and grain drying and threshing were estimated as 5, 15, 10, 2.5, 45 labor day ha ${ }^{-1}$.

Used plastic film per area $\left(\mathrm{Q}_{\text {film }}, \mathrm{kg} / \mathrm{ha}\right)$ was calculated as:

$$
\mathrm{Q}_{\text {film }}=\mathrm{F}_{\text {mulch }} \times \text { Thick }_{\text {film }} \times \rho_{\text {film }} \times 10000
$$

where $\mathrm{F}_{\text {mulch }}$ was the fraction of ground covered by plastic film (-); Thick film $_{\text {was }}$ the thick of plastic film (mm), $\rho_{\text {film }}$ was the density of polyethylene $\left(0.93 \mathrm{t} \mathrm{m}^{-3}\right)$. In this study, $\mathrm{F}_{\text {mulch }}$ was 0.68 , Thick film $_{\text {was }} 0.01 \mathrm{~mm}$. Thus, value of $\mathrm{Q}_{\text {film }}$ was $63.0 \mathrm{~kg} / \mathrm{ha}$ in this study.

\section{Statistical Analysis}

We used a one-way ANOVA to conduct analyses of variance with SAS v8.0 software (SAS Institute, Cary, NC, USA). Least significant differences (LSD) were used to detect the mean differences between the treatments. 


\section{Results}

\section{Effect of the 'one film for two years' system on the microclimate}

\section{Soil moisture}

Figure 1 shows the volumetric water content (VWC) at sowing during the second growing season for CK, PM1, and PM2. Compared to CK and PM1, the PM2 treatment effectively improved the soil moisture in the $0-10 \mathrm{~cm}(\mathrm{p}<0.01)$ and $10-20 \mathrm{~cm}(\mathrm{p}<0.05)$ depths. No significant difference was found for CK, PM1 and PM2 in the other soill layers.

Furthermore, we found that both PM1 and PM2 had no significant influence on the soil water storage in the $0-200 \mathrm{~cm}$ depth.

Figure 2 shows the soil water dynamic under CK, PM1 and PM2 treatments during the two growing seasons (2015 and 2016). Because there was no difference in management practices between the PM1 and PM2 treatments during the first growing season (2015 year), their average values were compared with CK. During the first growing season, the average VWC during the entire growing season of 2015 was $21.4 \%$ in the $0-20 \mathrm{~cm}$ layer, $19.1 \%$ in the $20-40 \mathrm{~cm}$ layer and $18.6 \%$ in the $60-100 \mathrm{~cm}$ layer of the PM1 treatment. This was 0.6 percentage points (pp), $0.9 \mathrm{pp}$ and $0.7 \mathrm{pp}$ higher than the corresponding value in the $\mathrm{CK}$ treatment $(\mathrm{p}<0.05, \mathrm{p}<0.05$, and $\mathrm{p}<0.05)$. The VWC was significantly higher in PM1 than in CK on the $62^{\text {nd }}$ and $103^{\text {rd }}$ day after sowing $(p<0.01)$ in the $0-20 \mathrm{~cm}$ and $20-60 \mathrm{~cm}$ layers and only on the $62^{\text {nd }}$ day in the $60-100 \mathrm{~cm}$ layer. No significant differences were found for other sampling times and soil layers.

During the growing season of 2016, we found that the VWC in PM2 was 2.3 pp, 1.0 pp and $0.7 \mathrm{pp}$ higher than under $\mathrm{CK}$ in the $0-20 \mathrm{~cm}, 20-60 \mathrm{~cm}$ and $60-100 \mathrm{~cm}$ depths $(\mathrm{p}<0.01$, $\mathrm{p}<0.01$, and $\mathrm{p}<0.05)$, and $0.8 \mathrm{pp}, 0.5 \mathrm{pp}$, and $0.3 \mathrm{pp}$ higher than PM1 $(\mathrm{p}>0.05, \mathrm{p}>0.05$, and $\mathrm{p}>0.05$ ), respectively. On $67 \%$ of the sampled dates, there was a significant difference between PM2 and CK in the $0-20 \mathrm{~cm}$ depth. In the $20-60 \mathrm{~cm}$ layer, only $20 \%$ of the sample 
dates exhibited a significant difference. A significant difference between PM2 and PM1 was observed on the $6^{\text {th }}$ day after sowing. This indicated that, compared to PM1, PM2 was helpful at improving the soil moisture at the seedling stage but had little influence on the average soil moisture during the growing season.

\section{Soil temperature}

The cumulative soil thermal time ( $\left.\mathrm{TT}_{\text {soil }}\right)$ was 1369 and 1499 for CK and PM1, respectively, for the whole growing season of 2015, and it was 1469, 1639 and 1609 for CK, PM1 and PM2 in 2016 (Figure 3). Compared to CK, PM1 resulted in a cumulative $\mathrm{TT}_{\text {soil }}$ increase of 130 and $169 \quad(\mathrm{p}<0.01)$ in 2015 and 2016, respectively. In 2016, the cumulative temperature was 140 higher in PM2 than in CK $(p<0.01)$. However, the difference between PM1 and PM2 was not significant.

Figure 3 also shows the evolution of $\mathrm{TT}_{\text {soil }}$ over the growing season in the different treatments. During the growing season, the gap of $\mathrm{TT}_{\text {soil }}$ between PM1 and CK was large in the early stage, and then it became smaller as time went on in both 2015 and 2016. In 2015, before the $90^{\text {th }}$ day (the time for reaching maximum canopy coverage), the average daily $\mathrm{TT}_{\text {soil }}$ was 1.1 higher in PM1 than in CK $(\mathrm{p}<0.01)$, and after the $90^{\text {th }}$ day, the average daily $\mathrm{TT}_{\text {soil }}$ was only 0.5 higher in PM1 ( $\left.\mathrm{p}>0.05\right)$. In 2016, the average daily $\mathrm{TT}_{\text {soil }}$ was 1.7 higher in PM1 than in CK $(\mathrm{p}<0.01)$ before the $90^{\text {th }}$ day and only 0.3 higher after the $90^{\text {th }}$ day $(\mathrm{p}>0.05)$. In PM2, the average daily $\mathrm{TT}_{\text {soil }}$ was 0.02 higher before the $90^{\text {th }}$ day $(\mathrm{p}>0.05)$ and 0.5 lower after the $90^{\text {th }}$ day $(\mathrm{p}>0.05)$ compared with PM1; furthermore, $\mathrm{TT}_{\text {soil }}$ was 1.7 higher before the $90^{\text {th }}$ day $(\mathrm{p}<0.01)$ and 0.2 lower after 90th day $(\mathrm{p}>0.05)$ compared with CK.

\section{Effect of 'one film for two years' on maize yield and water use efficiency}

\section{Dry matter accumulation}

Figure 4 shows that the accumulation of aboveground dry matter was much quicker in mulched treatments than in CK. At the end of the growing season of 2015, the aboveground 
dry matter was $16 \%$ higher in PM1 than in $\mathrm{CK}(\mathrm{p}<0.01)$, and in 2016 , it was $12 \%$ higher in PM1 than in CK $(\mathrm{p}<0.05)$. No significant difference was found between PM2 and PM1, and the aboveground dry matter in PM2 was $10 \%$ higher than in CK at the end of the growing season of $2016(\mathrm{p}<0.05)$.

Maize yield, evapotranspiration and water use efficiency

PM2 resulted in only a slight loss of grain yield (2\%), compared to PM1 in our study (Table 2), and this difference was not even significant. Compared with $\mathrm{CK}$, we found that PM1 significantly improved the grain yield by $12.1 \%$ and $25.0 \%$ in 2015 and 2016 , respectively. In 2016, the grain yield improved by $20.2 \%$ in PM2 compared to CK. For the total grain yield in the 2015 and 2016 year, no difference between PM1 and PM2 was found; however, compared to $\mathrm{CK}$, the total grain yield in PM2 improved by $16.3 \%$.

Evapotranspiration slightly decreased with PM1 and increased with PM2. However, the differences were not significant. Compared to CK, the WUE improved by $15.4 \%$ and $25.9 \%$ with PM1 in 2015 and 2016, and it improved by $16.4 \%$ with PM2 in 2016 and by $15.5 \%$ on average in 2015 and 2016. No differences were found between PM1 and PM2.

\section{Cost-benefit analysis}

Table 3 shows the cost-benefit analysis of PM1, PM2 and CK. Compared to PM1, the PM2 treatment reduced the cost of plastic film and tillage but did not significantly reduce the benefit from maize grain, and it generated 21\% (342 US\$ ha $\left.{ }^{-1} 2 \mathrm{year}^{-1}\right)$ and 70\% (815 US\$ ha ${ }^{-1}$ 2year ${ }^{-1}$ ) higher economic profit than PM1 and CK, respectively. At the same time, compared to CK, profit improved by $8 \%$ (473 US $\$$ ha $^{-1} 2$ year $^{-1}$ ) in PM1 because of higher yields.

\section{Discussion}

During the growing season of 2015 and 2016, we observed relative higher soil water content in plastic mulching treatment than CK. This was in accordance with previous research (Zhou et al. 2009; Gong et al. 2017) which suggested that plastic mulching was effective at 
reducing soil evaporation and then improving the soil water content during the growing season. Our results indicated that PM2 improved the soil moisture at sowing time and at the seedling stage in the 0-20 cm layer compared to PM1. For most farmland in northern China, during the fallow period of spring maize (from October to April of the next year), the field water balance was usually negative because of limited precipitation (Piao et al. 2010; Guo et al. 2012). At our research site, the calculated potential evaporation was $167 \mathrm{~mm}$ during the fallow period between 2015 and 2016, and the observed precipitation was $121 \mathrm{~mm}$. This result was consistent with previous research by $\mathrm{Wu}$ et al. (2017) and Cai et al. (2015) that suggested that mulching practices during the fallow season could relieve drought stress that occurs at sowing time and in the earlier stages of maize growth. However, we did not observe significantly different ET between PM1, PM2 and CK for the overall growing season. Gong et al. (2017) reported that ET decreased by $9.3 \%$ under plastic mulching on the Loess plateau, whereas Fan et al. (2017) and Zhang et al. (2011) found that ET was not significantly reduced from plastic mulching and even increased. Those studies suggest that the effects of plastic mulching on ET may be influenced by environment variables. In PM2, although some holes appeared and the film was partly destroyed by weeds during the early stage of the growing season (as shown in Figure 5.b), no significant difference in seasonal average soil moisture was observed between PM1 and PM2. This phenomenon could be explained by three reasons: (1) the extent of film degree was not enough to induce a significant drop in soil moisture. The holes were only a very small part of the whole film, and most soil was still covered by plastic film; (2) the improvement in soil water content at planting may offset the soil moisture drop caused by film damage; and (3) the effect of plastic mulching was only prominent at the early stage of the growing season (Zhou et al. 2009; Li et al. 2012), which meant that the further film damage in the late growing season was negligible.

Although a slightly lower cumulative soil temperature was observed in PM2 compared to PM1, this difference was not significant. It was true that the light transmittance of transparent 
PE decreases over time because of dust accumulation and aging (Castellano et al. 2008); however, PM2 reduced the accumulation of drops beneath the film because of the existence of small holes (as shown in Figure 5). Moreover, because of the growth of weeds below the film in PM2, it established a larger insulating air gap, and greater heat storage, or less heat loss, may have occurred (Ham et al. 1993; Ham and Kluitenberg 1994). Furthermore, due to the effects of evaporation, PM2 still could improve the soil temperature because of the reduction in latent heat flux (Liu et al. 2010). Further quantitative research is needed to reveal the soil water and heat flux and their loop in PM2 and to explain the interaction between different factors. Furthermore, our results confirmed that PM2 has equivalent performance to PM1 in terms of soil moisture and temperature adjustment.

Previous research indicated that modifications in plastic mulching on the microclimate were able to reduce the temperature and water stress and then led to improvements in crop yield (Qin et al. 2015; Fan et al. 2017; Zhang et al. 2011), and this was confirmed by our research. Moreover, no significant difference in maize yield was found from PM1 and PM2. Although the soil water content improved from PM2 in 0-20 cm before sowing and at the seedling stage, it seemed to have little influence on the average soil moisture over the whole growing season and on the ET in our research site. Soil moisture and temperature were the two most important factors influencing crop growth (Raes et al. 2009), and similar soil moisture and temperature dynamics in PM1 and PM2 may be able to explain their consistency in maize yield. This result was similar to Wu et al. (2017) in which the advantage of mulching throughout the whole season on maize yields was only found in one of three tested years.

Our results indicated that the WUE was significantly improved by PM1 and PM2 and that there was no significant difference between PM1 and PM2. This finding agreed with previous research (Liu et al. 2010; Xu et al. 2015; Qin et al. 2015). Liu et al. (2010) reported that the WUE of maize improved by $23-25 \%$ in a two-year experiment on the Loess Plateau. Xu et al. (2015) reported that the WUE of maize increased by $16 \%$ in plastic mulching treatment at five 
sites in northeastern China. Qin et al. (2015) reported that the mean effect of plastic mulching on WUE was $81 \%$ at high $\mathrm{N}$ input and $30 \%$ at low $\mathrm{N}$ input for maize in a meta-analysis. With similar ET in PM1, PM2 and CK, the impermeable barrier in PM1 and PM2 was probably effective at reducing the evaporation and increasing the physiologically significant canopy transpiration and plant productivity (Liu et al. 2010). Moreover, by applying PM2, the significant improvement in soil moisture in 0-20 cm meant that PM2 truly reduced water evaporation during the fallow period and made water resources more available for crop growth in the fallow period. The improvement in topsoil moisture was especially important for the seedling stage because the maize roots were mainly distributed in the topsoil during the seedling stage (Chassot et al. 2001). However, in the second year of this research, although the soil water content in the $0-20 \mathrm{~cm}$ layer was lower in PM1, it immediately improved from the rainfall, and severe spring drought did not occur. This may explain why PM1 and PM2 had similar WUE in this study. However, considering that the frequency of agricultural drought is increasing (Leng et al. 2015; He et al. 2016; Piao et al. 2010), the effects of PM2 on WUE were probably more predominant in drought years.

Our research suggests that PM2 was effective at improving economic profits. In fact, canceling maize price protection in China led to reductions in maize prices, and cost savings practices became more important than yield improvements for profit generation. At prevailing prices, compared to PM1, the cost for plastic film, tillage, film laying, film remove were reduced by 481 US $\$$ ha $^{-1} 2$ years $^{-1}$ in PM2. This was the main reason for the improvement in profits in PM2. Prices and difference of maize yield between PM1 and PM2 may vary with time and regions. Our data indicated that $1 \%$ change in the prevailing prices of plastic film, labor, tillage, film laying, maize grain, and reported difference of maize yield between PM1 and PM2 would induce $0.37 \%, 0.36 \%, 0.55 \%, 0.14 \%,-0.41 \%$ and $-0.41 \%$ change in the advantage of PM2 over PM1 on net benefits (i.e. net benefits in PM2 minus net benefits in 
PM1). This suggested PM2 was economically viable at relative large range of prices and yield difference between PM1 and PM2.

The shortcoming of this research was that we just tested the performance of 'one film for 2 years'. In fact, on the basis of current research, 'one film for multiple years' may have more advantages for plastics pollution control and economic benefits. However, the 'one film for multiple years' system called for an innovative design of plastic film that has good durability, weathering ability and high tensile strength (to reduce film destruction caused by wind and weeds). In fact, to control 'white pollution', some local governments in China (such as Xinjiang, Gansu, and Ningxia province) have released new mandatory standards for plastic film, and films with a thickness less than $0.010 \mathrm{~mm}$ have stopped being used in those places and the government encouraged farmers to use film with good durability and weathering ability. This provided favourable conditions for the application of a 'one film for 2 years' or 'one film for multiple years' system. On the other hand, because of cost savings in the 'one film for 2 years' or 'one film for multiple years' system, promotion of a new type of film without an added burden to farmers became possible. However, the design of film for a 'one film for multiple years' system and evaluation of its agricultural and ecological effects require further research.

\section{Conclusion}

In this study, the influences of 'one film for 2 years' system on soil moisture, temperature, maize yield, water use efficiency and cost-benefit balance were evaluated on the Loess Plateau. The results suggested: Compared to PM1, PM2 significantly improved the soil moisture in the $0-20 \mathrm{~cm}$ layer at planting and at the seedling stage, and this effect did not induce an increase in the average soil moisture and ET for the overall growing season; PM2 had no significant influence on the cumulative soil temperature compared to PM1, however, compared to CK, the cumulative soil temperature improved by 140 ; PM2 had no significant 
influence on maize yield and WUE compared to PM1, and compared to CK, they improved by $16.3 \%$ and $15.5 \%$, respectively; Because of the lower cost of plastic film and tillage, and due to similar maize yields to PM1, PM2 improved the economic profits by $21 \%$ and $70 \%$ compared to PM1 and CK.

\section{Acknowledgements}

We would like to thank the University of Liège-Gembloux Agro-Bio Tech and, more specifically, the research platform Terra Research \& Teaching Center for the scientific stay in Belgium that made this paper possible.

\section{Funding:}

This work was supported by the National Natural Science Foundation (31370522; 31660375).

\section{Reference}

Allen RG, Pereira LS, Raes D, Smith M. 1998. Crop evapotranspiration: guidelines for computing crop water requirements. FAO Irrigation and Drainage. Paper no. 56.Rome: Food and Agriculture Organization of the United Nations.

Cai T, Zhang C, Huang Y, Huang H, Yang B, Zhao Z, Zhang J, Jia Z. 2015. Effects of different straw mulch modes on soil water storage and water use efficiency of spring maize (Zea mays L.) in the Loess Plateau of China. Plant Soil Environ. 61(6):253-259.

Çakir R. 2004. Effect of water stress at different development stages on vegetative and reproductive growth of corn. Field Crop Res. 89(1):1-16.

Castellano S, Mugnozza GS, Russo G, Briassoulis D, Mistriotis A, Hemming S, Waaijenberg D. 2008. Plastic nets in agriculture: a general review of types and applications. Appl Eng Agric. 24(6):799-808. 
Chassot A, Stamp P, Richner W. 2001. Root distribution and morphology of maize seedlings as affected by tillage and fertilizer placement. Plant Soil. 231(1):123-135.

Chen YS, Wu CF, Zhang HB, Lin QY, Hong YW, Luo YM. 2013. Empirical estimation of pollution load and contamination levels of phthalate esters in agricultural soils from plastic film mulching in China. Environ Earth Sci. 70(1):239-247.

Dong H, Liu T, Li Y, Liu H, Wang D. 2013. Effects of plastic film residue on cotton yield and soil physical and chemical properties in xinjiang.Trans Chin Soc Agric Eng. 29(8):91-99. Chinese.

Fan YQ, Ding RS, Kang SZ, Hao XM, Du TS, Tong L, Li S. 2017. Plastic mulch decreases available energy and evapotranspiration and improves yield and water use efficiency in an irrigated maize cropland. Agric Water Manage. 179(1):122-131.

FAO. 2006. Word Reference Base for Soil Resources 2006-A Framework for International Classification, Correlation and Communication. World Soil Resources Reports. Rome: FAO.

Godfray HCJ, Beddington JR, Crute IR, Haddad L, Lawrence D, Muir JF, Pretty J, Robinson S, Thomas SM, Toulmin C. 2010. Food Security: The Challenge of Feeding 9 Billion People. Science. 327(5967):812-818.

Gong D, Mei X, Hao W, Wang H, Caylor KK. 2017. Comparison of ET partitioning and crop coefficients between partial plastic mulched and non-mulched maize fields. Agric Water Manage. 181:23-34.

Guo SL, Zhu HH, Dang TH, Wu JS, Liu WZ, Hao MD, Li Y, Syers JK. 2012. Winter wheat grain yield associated with precipitation distribution under long-term nitrogen fertilization in the semiarid Loess Plateau in China. Geoderma. 189 (6):442-450.

Guo YF, Li SY, Huo YZ. 2016. The effects of different residual film amount on spring maize production traits and soil moisture. Water Sav Irri. 4:47-49.Chinese. 
Guto SN, Pypers P, Vanlauwe B, De RN， Giller KE. 2011. Tillage and vegetative barrier effects on soil conservation and short-term economic benefits in the central kenya highlands. Field Crop Res. 122(2):85-94.

Ham JM, Kluitenberg GJ, Lamont WJ. 1993. Optical properties of plastic mulches affect the field temperature regime. J Am Soc Hortic Sci. 118 (2):188-193.

Ham JM, Kluitenberg GJ. 1994. Modeling the effect of mulch optical properties and mulchsoil contact resistance on soil heating under plastic mulch culture. Agr Forest Meteorol. 71(3):403-424.

He J, Yang XH, Li Z, Zhang XJ, Tang QH. 2016. Spatiotemporal Variations of Meteorological Droughts in China During 1961-2014: An Investigation Based on MultiThreshold Identification. Int J Disaster Risk Sci. 7(1):63-76.

He WQ, Yan CR, Zhao CX, Chang RQ, Liu Q, Liu S.2009. Study on the pollution by plastic mulch film and its countermeasures in china. J Agro-Environ Sci. 28:533-538. Chinese.

Leng GY, Tang QH, Rayburg S. 2015. Climate change impacts on meteorological, agricultural and hydrological droughts in China. Global Planet Change. 126(126):2334.

Li R, Hou XQ, Jia ZK, Han QF, Yang BP. 2012. Effects of rainfall harvesting and mulching technologies on soil water, temperature, and maize yield in Loess Plateau region of China. Soil Res. 50(2):105-113.

Liu EK, He WQ, Yan CR. 2014. 'White revolution' to 'white pollution'-agricultural plastic film mulch in China. Environ Res Lett. 9(9):3.

Liu Y, Yang SJ, Li SQ, Chen XP, Chen F. 2010. Growth and development of maize (Zea mays L.) in response to different field water management practices: Resource capture and use efficiency. Agr Forest Meteorol. 150(4):606-613.

McMaster GS, Wilhelm WW. 1997. Growing degree-days: one equation, two interpretations. Agr Forest Meteorol.87(4):291-300. 
Miedema P. 1982.The effects of low temperature on Zea mays. Advan Agron. 35:93-128.

National Bureau of Statistics of China (CN). 2014. China Statistical Yearbook. Beijing: China Statistics Press. Chinese.

[NDRC] National Development and Reform Commission (CN). 2016. Compilation of national cost and income of agricultural products 2016. Beijing: China Statistics Press. Chinese.

Niu W, Zou X, Liu J, Zhang M, Lü W, Gu J. 2016. Effects of residual plastic film mixed in soil on water infiltration, evaporation and its uncertainty analysis. Trans Chin Soc Agric Eng. 32:110-119. Chinese.

Payero JO, Tarkalson DD, Irmak S, Davison D, Petersen JL. 2008. Effect of irrigation amounts applied with subsurface drip irrigation on corn evapotranspiration, yield, water use efficiency, and dry matter production in a semiarid climate. Agric Water Manage. 95(8):895-908.

Piao SL, Ciais P, Huang Y, Shen ZH, Peng SS, Li JS, Zhou LP, Liu HY, Ma YC, Ding YH, et al. 2010. The impacts of climate change on water resources and agriculture in China. Nature. 467(7311):43-51.

Qin W, Hu CS, Oenema O. 2015. Soil mulching significantly enhances yields and water and nitrogen use efficiencies of maize and wheat: a meta-analysis. Sci Rep-UK. 5:13.

Raes D, Steduto P, Hsiao TC, Fereres E. 2009. AquaCrop the FAO crop model to simulate yield response to water: II. Main algorithms and software description. Agron J. 101(3):438-447.

Tarara JM. 2000. Microclimate modification with plastic mulch. Hortscience. 35(2): 169-180. Tilman D, Balzer C, Hill J, Befort BL. 2011. Global food demand and the sustainable intensification of agriculture. Proc Natl Acad Sci USA. 108(50):20260-20264. UNDP. 2006. Human Development Report 2006. Beyond Scarcity: Povert, Poverty and the Global Water Crisis. New York (NY): Palgrave Macmillan. 
UNEP. 1992. World atlas of desertification. London:Edward Arnold.

Wu Y, Huang FY, Jia ZK, Ren XL, Cai T. 2017. Response of soil water, temperature, and maize (Zea may L.) production to different plastic film mulching patterns in semi-arid areas of northwest China. Soil Till Res. 166:113-121.

Xu J, Li CF, Liu HT, Zhou PL, Tao ZQ, Wang P, Meng QF, Zhao M. 2015. The Effects of Plastic Film Mulching on Maize Growth and Water Use in Dry and Rainy Years in Northeast China. Plos One. 10(5):e0125781.

Yan CR, He WQ, Neil C. 2014. Plastic-film mulch in Chinese agriculture: Importance and problems. World Agric. 4(2):32-36.

Zhang SL, Li PR, Yang XY, Wang ZH, Chen XP. 2011. Effects of tillage and plastic mulch on soil water, growth and yield of spring-sown maize. Soil Till Res.112(1):92-97.

Zhou LM, Li FM, Jin SL, Song Y. 2009. How two ridges and the furrow mulched with plastic film affect soil water, soil temperature and yield of maize on the semiarid Loess Plateau of China. Field Crop Res. 113(1):41-47. 
Table 1. Prevailing prices for inputs and outputs used for calculation of cost-benefit balance

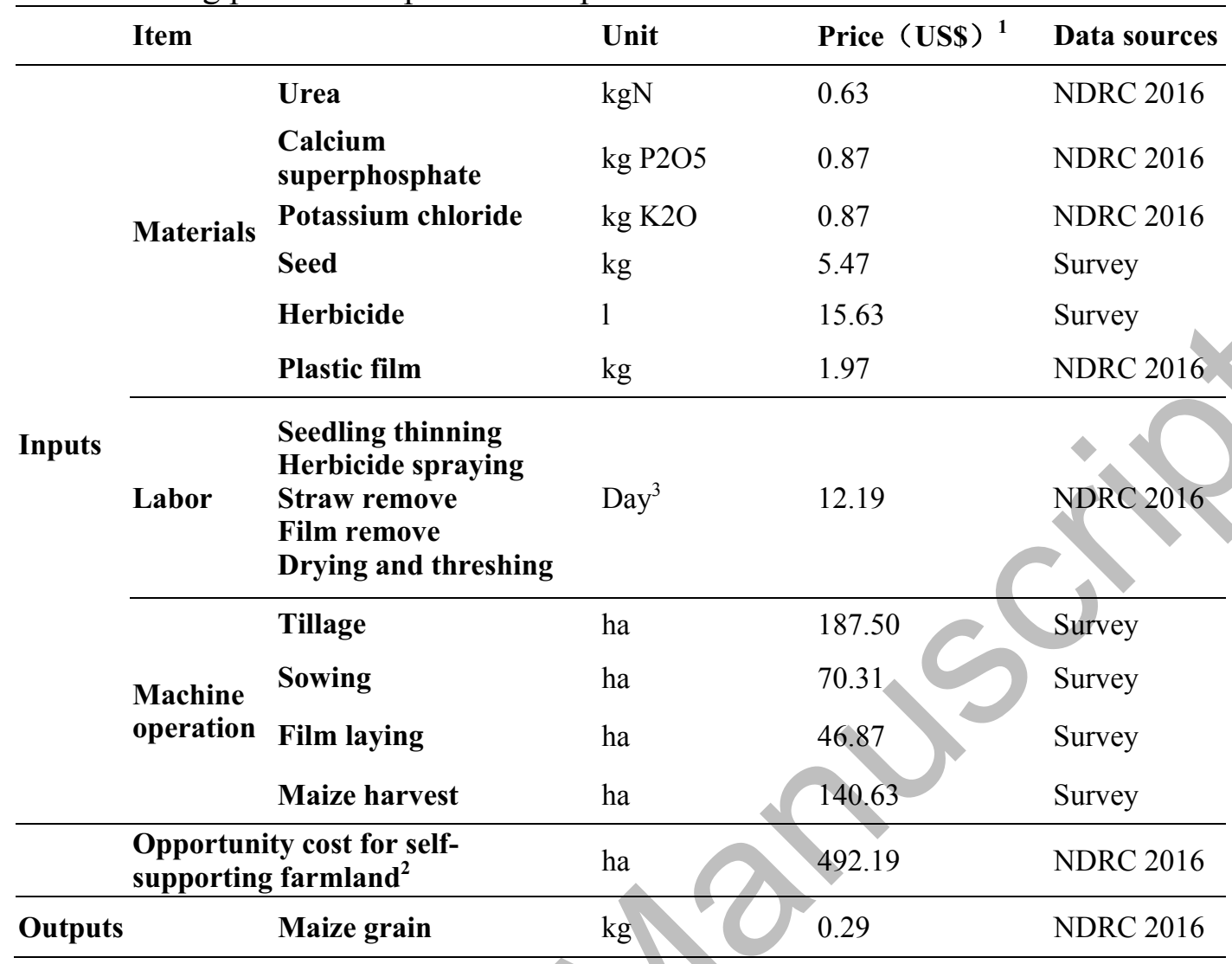

Note: 1.US\$1=6.4 RMB Yuan, according to the average exchange rate in 2015 and 2016, Bank of China; 2. Opportunity cost for self-supporting farmland meant the lost earning from renting out farmland when farmers manage their farmland by themselves; 3.1 Day $=8$ hours for a medium labour. 
Table 2. Maize grain yield, evapotranspiration (ET) and water use efficiency (WUE) of fields without plastic mulching (CK), replacing film annually (PM1) and one film for two seasons (PM2) treatments.

\begin{tabular}{ccccc}
\hline & & CK & PM1 & PM2 \\
\hline $\begin{array}{c}\text { Grain } \\
\left(\text { kg ha }^{-1}\right)\end{array}$ & $\mathbf{2 0 1 5}$ & $9464 \mathrm{~b}$ & $10608 \mathrm{a}$ & $10608 \mathrm{a}$ \\
& $\mathbf{2 0 1 6}$ & $10020 \mathrm{~b}$ & $12529 \mathrm{a}$ & $12047 \mathrm{a}$ \\
& Total & $19484 \mathrm{~b}$ & $23137 \mathrm{a}$ & $22656 \mathrm{a}$ \\
\hline $\mathbf{E T}$ & $\mathbf{2 0 1 5}$ & $377 \mathrm{a}$ & $368 \mathrm{a}$ & $368 \mathrm{a}$ \\
$\mathbf{( m m )}$ & $\mathbf{2 0 1 6}$ & $440 \mathrm{a}$ & $437 \mathrm{a}$ & $454 \mathrm{a}$ \\
& Average & $816 \mathrm{a}$ & $804 \mathrm{a}$ & $822 \mathrm{a}$ \\
\hline $\mathbf{W U E}^{-\mathbf{1}}$ & $\mathbf{2 0 1 5}$ & $25.1 \mathrm{~b}$ & $29.0 \mathrm{a}$ & $29.0 \mathrm{a}$ \\
& $\mathbf{2 0 1 6}$ & $22.8 \mathrm{~b}$ & $28.7 \mathrm{a}$ & $26.5 \mathrm{a}$ \\
& Average & $23.9 \mathrm{~b}$ & $28.8 \mathrm{a}$ & $27.6 \mathrm{a}$ \\
\hline
\end{tabular}

Note: Numbers in each column followed by different letters indicate significant $(\mathrm{P} \leq 0.05)$ differences between treatments according to LSD tests. 
Table 3. Total cost, benefits and net benefits in 2015 and 2016 for fields without plastic mulching (CK), replacing film annually (PM1) and one film for two seasons (PM2) treatments. (Monetary unit: US\$ ha ${ }^{-1} 2$ years $^{-1}$ ).

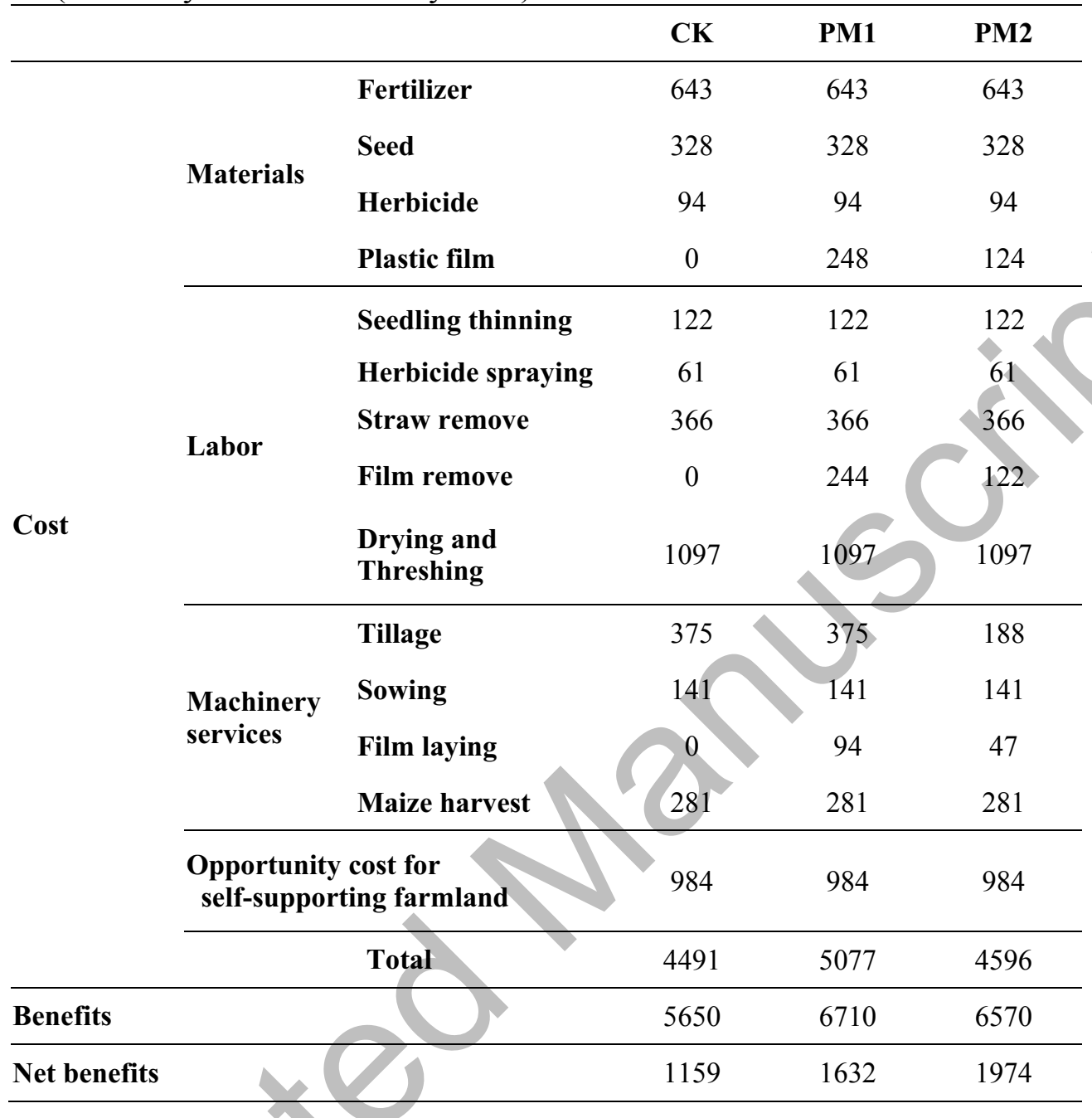




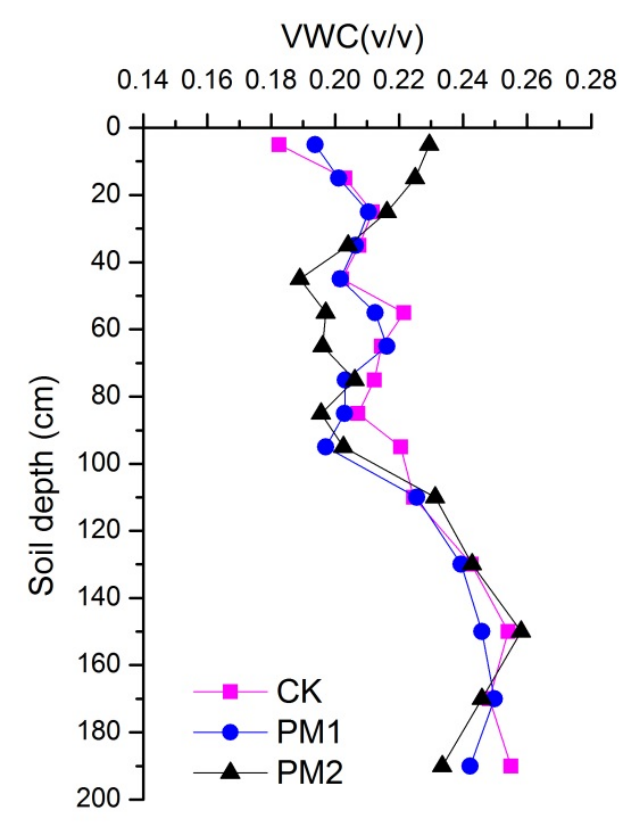

Figure 1. Volumetric water content (VWC) at sowing time during the second growing season (2016) on fields without plastic mulching (CK), replacing film annually (PM1) and one film for two seasons (PM2) treatments. 
(a) 2015

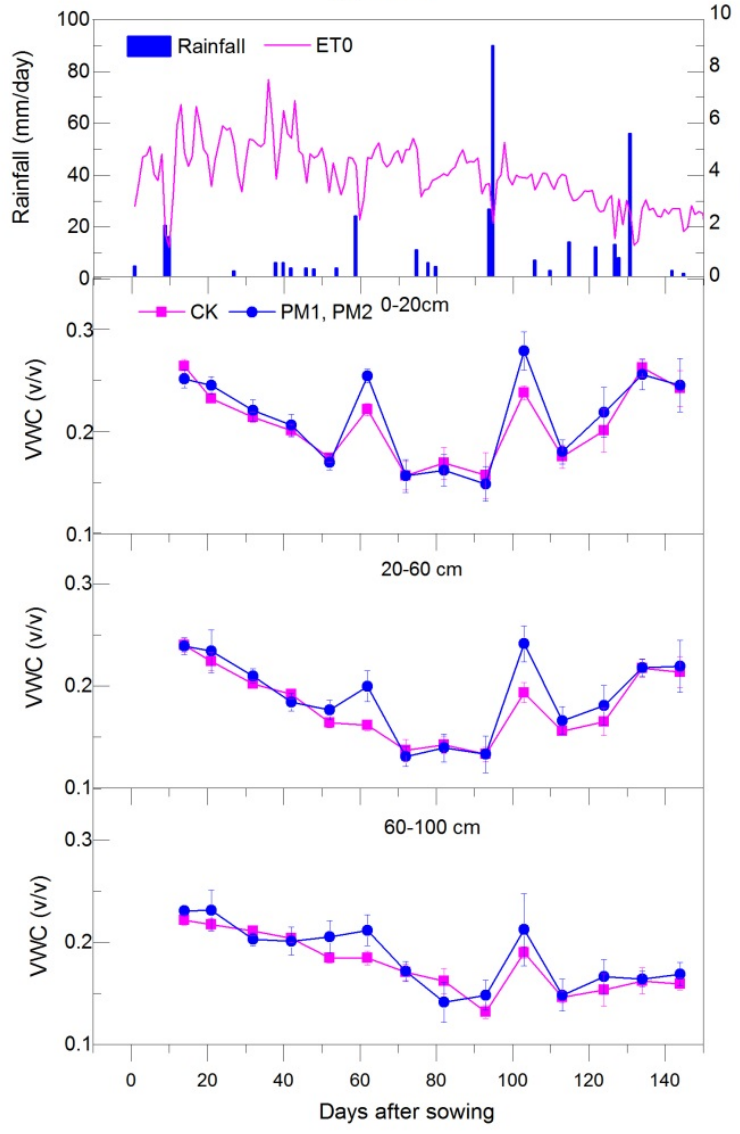

(b) 2016

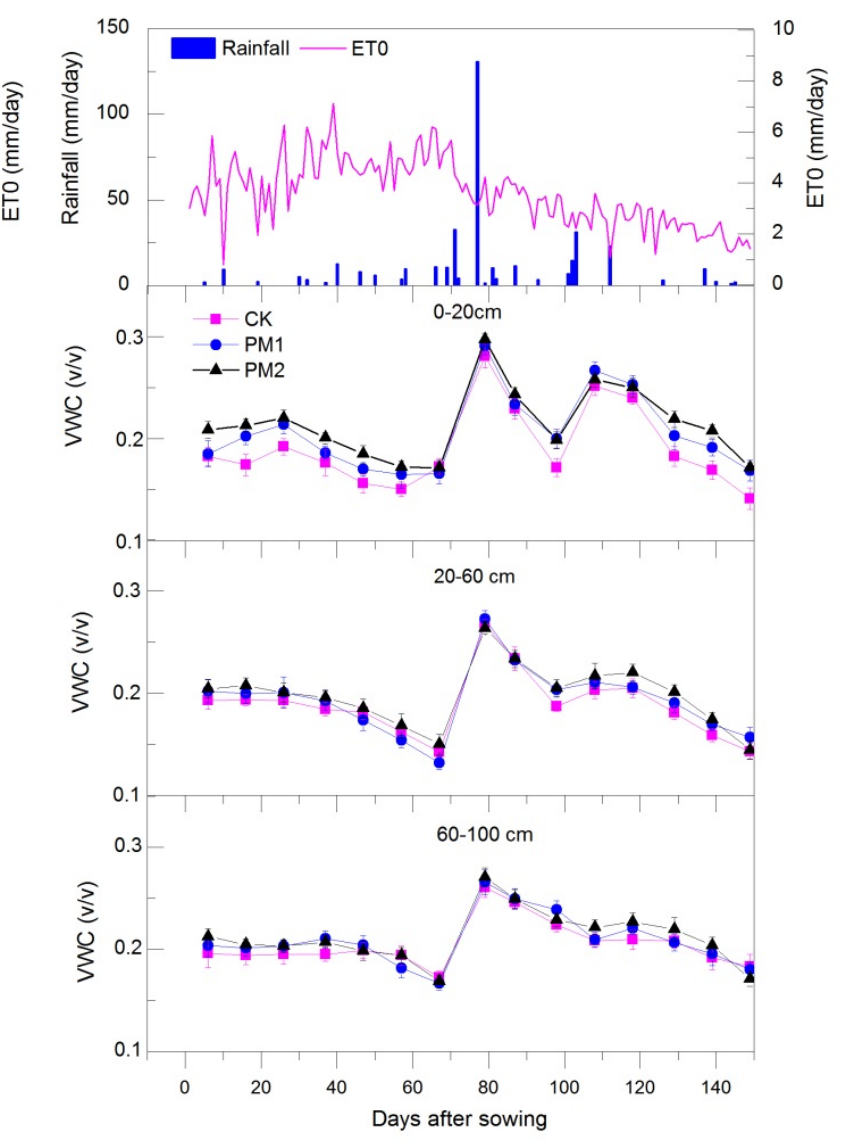

Figure 2. The volumetric water content (VWC) during the growing seasons of 2015 and 2016 on fields without plastic mulching (CK), replacing film annually (PM1) and one film for two seasons (PM2) treatments. 

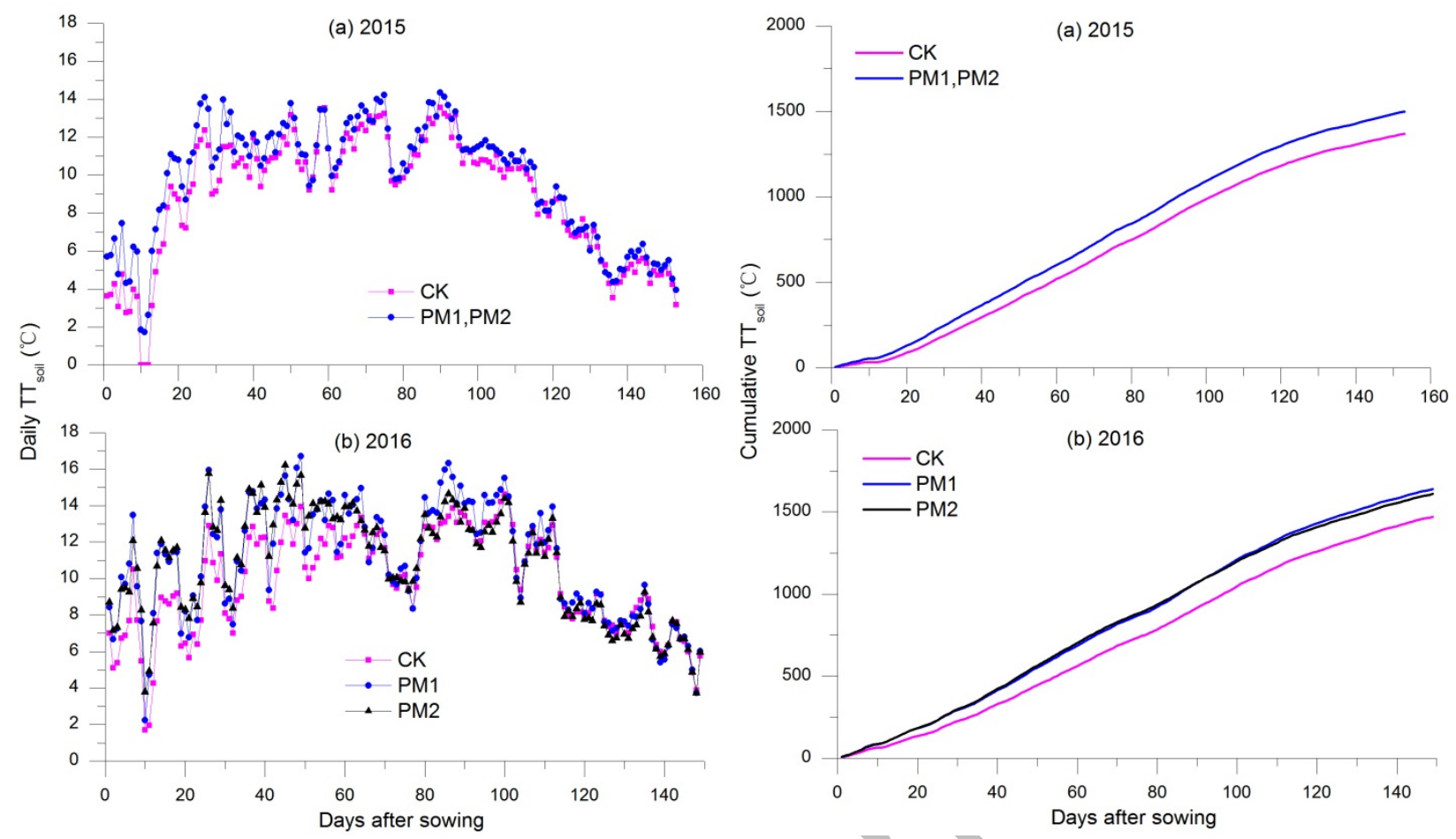

Figure 3. Daily and cumulative soil thermal time $\left(\mathrm{TT}_{\text {soil }}\right)$ during the growing season of 2015 and 2016 on fields without plastic mulching (CK), replacing film annually (PM1) and one film for two seasons (PM2) treatments. 


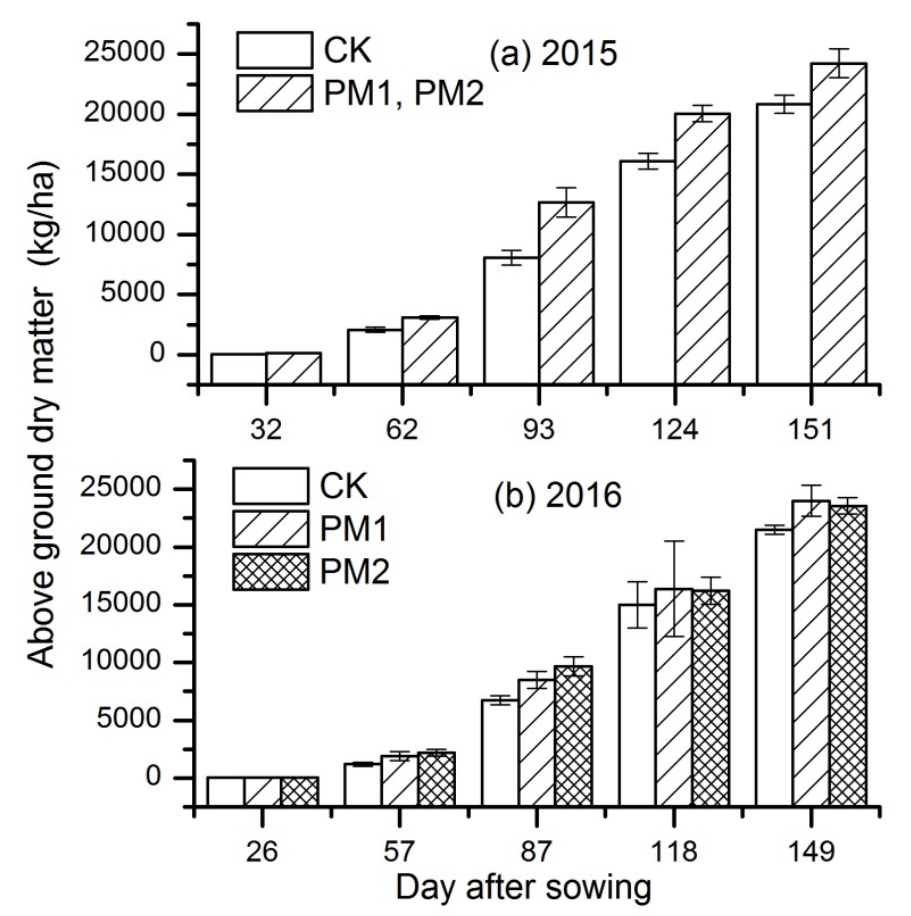

Figure 4. Accumulation of aboveground dry matter during the growing season of 2015 and 2016 for the field without plastic mulching (CK), replacing film annually (PM1) and one film for two seasons (PM2) treatments. 

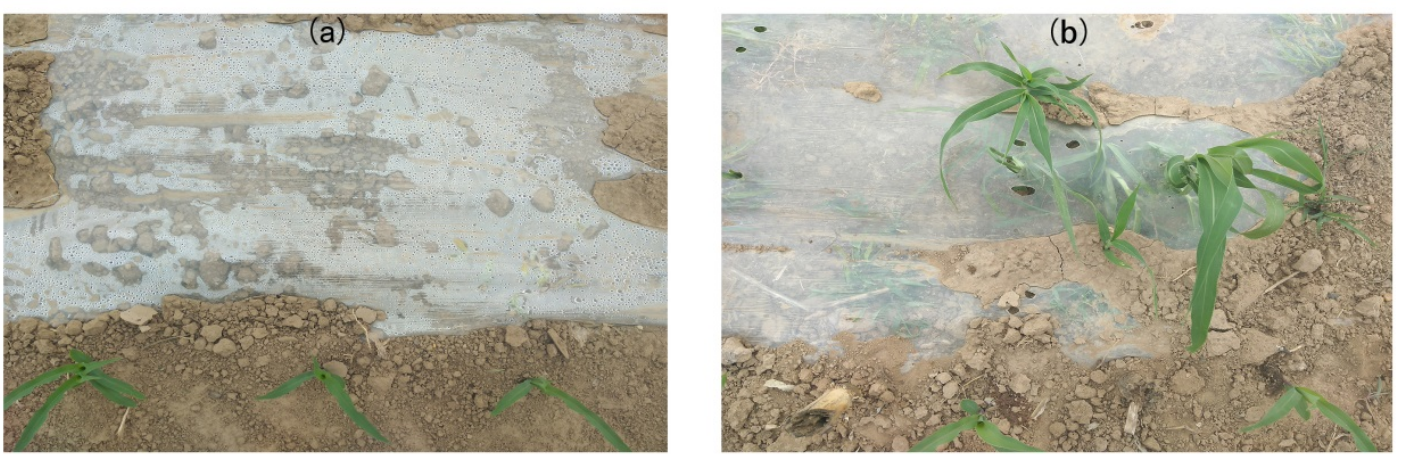

Figure 5. Film destruction in the 'one film for two seasons' treatment (b) during the early stage of the second growing season and a comparison with the replacing film annually treatment (a).

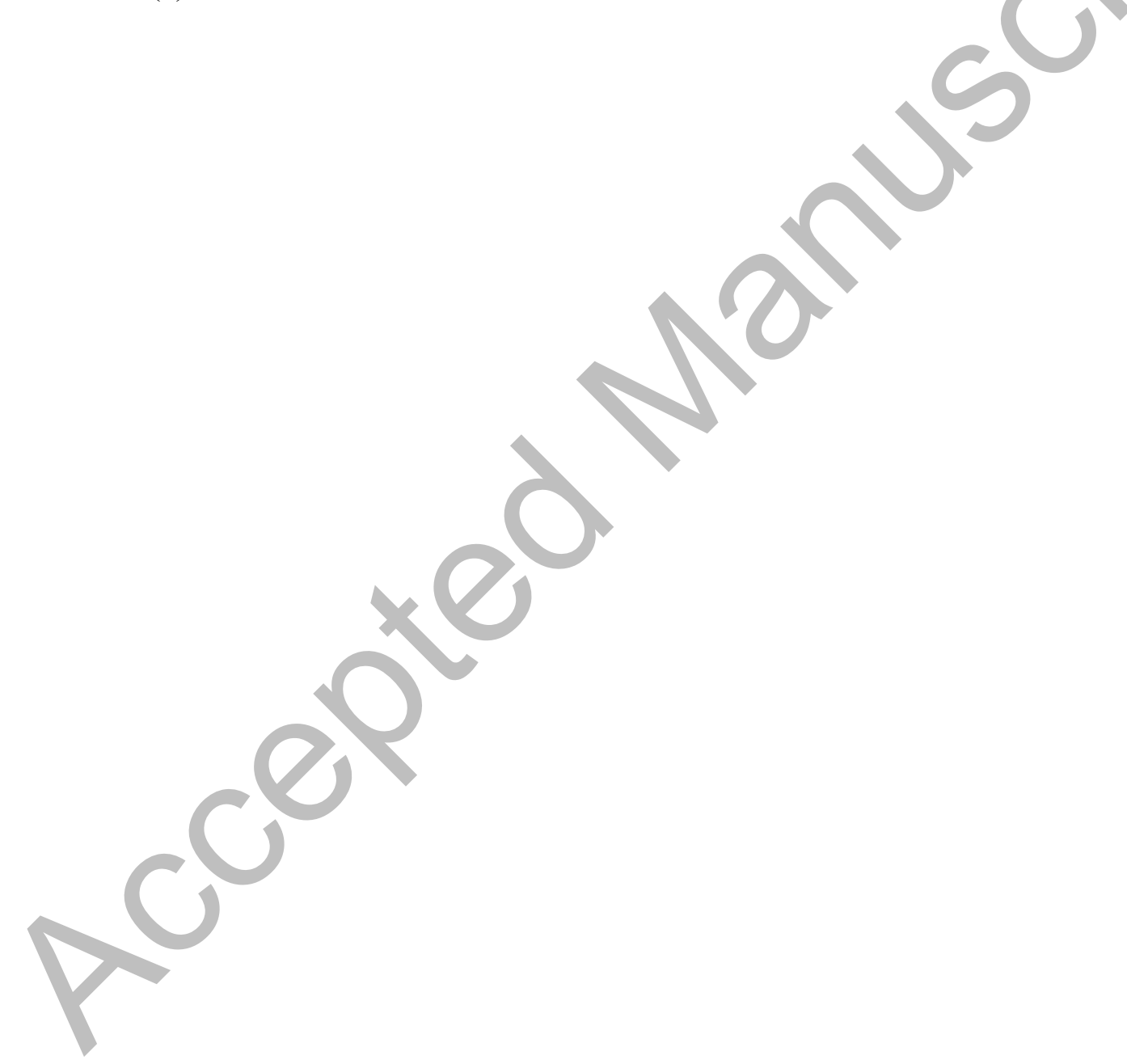

